TILTAI, 2017, 3, 115-128 ISSN 1392-3137 (Print), ISSN 2351-6569 (Online)

\title{
DOMESTIC VIOLANCE AGAINST WOMEN: DISCOURSE OF REALITY
}

\author{
ArūnasAcus, ElvyraAcienė, Dalia Puidokienè \\ Klaipéda University, Klaipéda Family and Child Welfare Center
}

\begin{abstract}
The article deals with the problem of domestic violence against women and assesses the expression of this phenomenon in the context of a society approach. The statistical construct of this phenomenon confirms the assumption that the establishment of legal fundamentals for protection against violence is linked to a process of changing the society approach to this issue. The analysis of theoretical and legal discourse of domestic violence reveals that the consistent implementation of the strategy of legal protection of victims against domestic violence has enabled the creation of a specialized comprehensive assistance infrastructure system throughout the country, which provides access to appropriate medical, psychological, legal assistance and at the same time entitles the society to develop prevention programmes that help to establish intolerance towards violence. The Republic of Lithuania Law on Protection against Domestic Violence (2011) has laid strong foundations for the establishment of specialized assistance centres and implies the development of necessary infrastructure.

KEYWORDS: violence against women, Republic of Lithuania Law on Protection against Domestic Violence, specialized assistance centre.
\end{abstract}

\begin{abstract}
Anotacija
Šiame straipsnyje autoriai analizuoja smurto prieš moterị artimoje aplinkoje problemą, šio fenomeno raišką vertindami visuomenès požiūrio kontekste. Pateikdami šio reiškinio statistinį konstruktą patvirtina faktą, kad apsaugos nuo smurto teisinès bazės kūrimas yra ir visuomenės požiūrio keitimo procesas. Analizuodami smurto prieš moteris artimoje aplinkoje teorinį ir teisinį diskursą autoriai atskleidžia, kad nuosekliai vykdoma teisinès apsaugos nuo smurto artimoje aplinkoje strategija leido Lietuvoje sukurti specializuotos kompleksinès pagalbos infrastruktūrą, kuri, apimdama visos šalies savivaldybes, suteikia asmenims, patyrusiems smurtą artimoje aplinkoje, galimybę gauti reikalingą medicininę, psichologinę ir teisinę pagalbą, kartu ịgalina visuomenę kurti prevencines programas, padedančias formuoti netoleruojantị požiūrị ị smurtą. LR Apsaugos nuo smurto artimoje aplinkoje įstatymas (2011) padejjo tvirtus specializuotų pagalbos centrų pagrindus, kas suponuoja šios infrastruktūros tobulinimo prieigas.

PAGRINDINIAI ŽODŽIAI: smurtas prieš moteris, LR Apsaugos nuo smurto artimoje aplinkoje įstatymas, specializuotos pagalbos centras.
\end{abstract}

\section{Introduction}

Domestic violence is qualified as the violation of human rights. In Lithuania this type of violation has long been understood as an internal family affair. Only after the entry into force of the Law on Protection against Domestic Violence (LR Apsaugos nuo smurtos artimoje aplinkoje istatymas, 2011) the perception of this 
problem has exceeded the boundaries of families and has become a cause of public interest with the purpose to ensure family safety and positive functioning.

Resolution on the adoption of 2014-2020 Programme on Prevention of Domestic Violence and Provision of Assistance to Victims (Dèl valstybinès smurto artimoje aplinkoje prevencijos ir pagalbos teikimo nukentejusiems asmenims 2014-2020 metu programos patvirtinimo, 2014) specifies that the solution to the problem is inseparable from how society perceives the violence in the immediate environment, since only in the context of the problem concept it is possible to discuss and decide about the responsibility of a perpetrator, the preconditions for the change of violence, victim assistance and prevention.

The issue of domestic violence has been the object of research already before 2011 when the law on Protection against domestic violence (Apsaugos nuo smurtos artimoje aplinkoje istatymas, 2011), was adopted. Since the very first years of the re-establishment of Lithuania Independence the question of violence against women has been addressed from the cultural, sociological, demographic and legal points of view. The issue has been researched by A. Purvaneckas, G. Purvaneckiene (1995; 2000; 2001), K. Miškinis (2003), V. Kanopienė, M. A. Pavilionienė (1997; 1998), L. Meškauskaitè (1999), G. Navaitis (1999), B. Palavinskienè, S. Vidrinskaitè (2002), M. Gustainienè (2005), L. Jūrienè (1998), M. Gaigalienè (2002), N. Dirsienè, V. Reikertienè (2005; 2008), J. Reingarde, L. Tamutiene (2004; 2010). After the adoption of the law on Protection against domestic violence in 2011(Apsaugos nuo smurtos artimoje aplinkoje įstatymas, 2011) there search on this issue has been continued by I. Dirgèlienè, O. Jundulaitè (2011), S. Rutkauskienė, J. GudliauskaitèGodvadè (2011), L. Vaigè (2013; 2016), S. Zaksaitè (2014), etc. The research has not only revealed the extent and legal loopholes, but also the problems of gender identity that relate to the functioning of a family, possibilities of self-expression of a woman at work and in the society. Among different forms of violence, the mostly wide-spread and frequently recognisable is physical violence. However, the society acknowledges that it is also important to identify and diagnose the psychological, economic and sexual violence. The co-author of this study D. Puidokiene (2002) has carried out the qualitative research into the expression of violence against women and resocialization possibilities. At that time the research stimulated active discussion among practitioners and academic society. Fifteen years later the authors of this article decided to conduct a longitudinal research and analyse the aspects of violence against women in the changed context of socio-cultural and legal world.

The object of the research: the expression of domestic violence against women and provision of assistance.

The purpose of the research: to unfold the reality of domestic violence against women and evaluate the assistance strategies. 
The theoretical expression of the concept of violence against women. In the scientific literature the concept of violence takes different directions. However, the general approach focuses on the understanding that violence equals the physical and emotional distress, bodily harm which is the result of the use of force with the purpose to abuse another person physically and psychologically, or forceful restriction of personal liberty that has great influence on normal existential conditions. The act of violence leads to the situation when a person becomes a non-living object.

Violence is:

- expression - a person expresses his/her extreme anger, rage or jealousy;

- manipulation - violence is used as a method to control others and achieve what is wanted;

- revenge - violence is used to take revenge on those who have previously conducted harm (Ministry of Health of the Republic of Lithuania / LR Sveikatos apsaugos ministerija, 2000, p. 3).

It is important to emphasize that the concept of domestic violence is usually understood as a complex phenomenon, involving psychological, physical, sexual and economic abuse (violence).

Most researchers distinguish the following forms of domestic violence:

- Physical violence. Physical abuse suppresses personality. Physical abuse involves such actions as blowing, kicking, sinking, pushing, locking in a closed space, poisoning or causing pain.

- Psychological violence. It can be of different types, such as social isolation, disregard, alienation, public humiliation, harassment, ignoring, jealousy, blackmail and persecution.

- Sexual violence. Constant sexual pressure, the use of force, threats or blackmail to coerce a woman into sexual relations. A person is treated as a sexual object.

- Economic violence. It is the situation when an adult family member deprives another adult family member of the opportunity to manage the family budget, refuses to maintain children, runs into debts, squanders money. Economic violence makes women extremely vulnerable and increases the likelihood of domestic violence (Miškinis, 2003, p. 309-312; Šeimos krizių prevencija, socialinès ir psichologinès pagalbos šeimai būdai, 2008, p. 79-81; Moterų informacijos centro tyrimo ataskaita, 2004, p. 2-3).

- Futility and neglect. Futility and neglect are understood as lack of attention towards a person, as well as deprivation of what is necessary for a family member to develop, grow up and mature. Children, grandparents and people with disabilities often suffer from this form of violence. Therefo- 
re, futility and neglect can also be characterized by the following profiles: medical, pedagogical, social, psychological, exclusion (Liobikienè, 2006, p. 92-93; Moteru informacijos centras, 2005, p. 7).

The given forms of domestic violence can be interrelated. Physical violence is at the same time the emotional suffering that greatly influences a psychological condition of a woman, and negatively affects her self-expression that projects the motivation of her professional ambitions.

\section{Theoretical and legal discourse of domestic violence against women}

In 1993 the United Nations General Assembly adopted the Declaration on the Elimination of Violence against Women (Deklaracija dèl smurto prieš moteris panaikinimo, 1993). This was a very significant step in shaping the protection of women from violence around the world. On November 26, 2009 the European Parliament adopted a Resolution on the elimination of violence against women (Rezoliucija dèl smurto prieš moteris panaikinimo [Resolution on the elimination of violence against women], 2009, Nr. C 285 E / 07). The Declaration joined together all the relevant documents that have been approved before it: Elimination of violence against women. Commission on Human Rights Resolution 2003/45 (No. E/CN.4/RES/2003/45, December 22, 2003); Elimination of domestic violence against women. UN General Assembly Resolution (No. A/RES/58/147); Intensification of efforts to eliminate all forms of violence against women UN General Assembly Resolution (No. A/RES/61/143). The document assumes that "men's violence against women violates human rights to life, security, dignity, physical and mental integrity, the right to sexual and reproductive choices and health; men's violence against women is an obstacle in the participation of women in social activities, political and public life and in the labour market, and can lead to marginalization and poverty for women; men's violence against women goes hand in hand with violence against children and has an impact on children's psychological wellbeing and lives, and can create a cycle of violence and abuse which is perpetuated through generations; men's violence against women is a structural and widespread phenomenon in Europe and worldwide, a phenomenon that affects victims and perpetrators, regardless of their age, education, income or social status, and is linked to unequal distribution of power between women and men in our societies" (Rezoliucija dèl smurto prieš moteris panaikinimo [Resolution on the elimination of violence against women], 2009, Nr. C 285 E / 07).

This document has had impact not only on the EU, but also Lithuanian legal documents related to violence against women. 
Article 21 of the Constitution of the Republic of Lithuania recognizes the human right to the inviolability and dignity of a person, prohibits humiliation, harm, torture, and cruel treatment as well as different types of punishment (Lietuvos Respublikos Konstitucija, 2002).

The Criminal Code of the Republic of Lithuania (adopted on September 26, 2000 by the Seimas of the Republic of Lithuania; the law also approved the Code of Criminal Procedure and the Code of Conduct of Penalties, which were aligned with EU law and came into force on May 1,2003) has established positions which are punishable and which protect a person against crimes against health and life: Article 129, paragraph 3 for crimes against human life; Article 135, paragraph 3 for serious health disturbance; Article 138, paragraph 3 for a minor health disturbance; Article 140 for crimes against human health; Articles 142-145 define crimes that pose a threat to human health and life; Articles 149-153 describe crimes and criminal offences against freedom and inviolability of a person's sexual self-determination; Articles 156-164 directly target crimes and criminal offences against a child and a family. However, the appearance of new challenges of violence against a person makes it a necessity to initiate a process of constant update and amendment of the Criminal Code (LR baudžiamasis kodeksas, 2015).

The solution to the problem of violence in the immediate environment required a new and deeper legal analysis of the problem. The Law of the Republic of Lithuania on Protection against Domestic Violence (XI-1425) was adopted and came into force on December 15, 2011. Article 1 of this law states, that "the law aims at protecting persons against domestic violence, which, due to damage caused to society, is attributable to the acts of public importance, promptly respond to arising threats, undertake prevention measures, apply protection measures and provide appropriate assistance" and confirms the statement already established in the Constitution of the Republic of Lithuania (1992, Article 47) that "violence in the immediate environment is a violation of human rights and freedoms. This law defines the concept of domestic violence, identifies the rights and responsibilities of subjects of violence in the immediate environment, the implementation of preventive measures, the provision of assistance in the event of violence in the immediate environment, and the application of safeguards for the victim. The protection of the child against violence is also regulated by this Law and other legal acts of the Republic of Lithuania".

The law has a pronounced content of versatility because the immediate environment is treated as the environment comprising the persons currently or previously linked by marriage, partnership, affinity or other close relations, also the persons having a common domicile and a common household. Besides, the law aims at protecting women, children and men. And this fact is of great relevance. It can be acknowledged that six years after the adoption of the Law on Protection against 
Domestic Violence, it has protected a large number of women and children who were victims of domestic violence, since the adoption of this law has abolished the private accusation scheme, and domestic violence has been regarded as a violation of human rights and liberties (Apsaugos nuo smurto artimoje aplinkoje istatymo prièmimo istorija [History of the Law on Protection against Domestic Violence], 2010-2011). The law provides for assistance and prevention opportunities. Preventive measures should aim at everyone as an endeavour to develop constructive, non-violent intercourse among relatives.

The Law on Protection against Domestic Violence was amended two times during the years 2013-2014. The amendments specify the financial procedure of preventive measures for persons who have suffered from violence in the immediate environment. On July 2, 2013 the amendments to the Criminal Code and the Code of Criminal Procedure were adopted to harmonize these codes with the Law on Protection against Domestic Violence. These amendments provided that whenever a criminal offence has signs of domestic violence, the pre-trial investigation begins, regardless of whether there is or is no statement of the victim's complaint or his legal representative (Baudžiamojo proceso kodekso straipsnių pakeitimo ir papildymo įstatymas [Law on the Amendment of the Articles of the Code of Criminal Procedure], 2013).

The adoption of amendments to the Law on the Protection against Domestic Violence and the adoption by Government of the Republic of Lithuania Resolution (No. 485 of May 28, 2014) of 2014-2020 Programme on Prevention of Domestic Violence and Provision of Assistance to Victims (Dèl Valstybinès smurto artimoje aplinkoje prevencijos ir pagalbos teikimo nukentejusiems asmenims 2014-2020 metu programos patvirtinimo, 2014) have opened wider possibilities to the solution of the domestic violence problem and also it considered to be a positive measure to reduce the level of domestic violence in the country.

However, the reality of life has generated new challenges. In 2014 Human Rights Monitoring Institute conducted a study on the issues of domestic violence. The research was carried out by officials, prosecutors and judges who pointed out that the law lacks clarity in the regulation of protective measures and that victims of crime are not fully assisted with legal, psychological and social support. The research analyses was based on the issues of Directive of the Rights of the Victims of Crimes: A New Approach to Victims of Domestic Violence (Nusikaltimų aukų teisiu direktyva: naujas požiūris ị artimųjų smurto aukas, 2014). The study also drew attention to the fact that criminal law, while helping to combat the hidden aspects of violent domestic crimes, cannot automatically overcome the causes and consequences of domestic crime, and therefore appropriate prevention, psychological, social and other services are necessary to be implemented. 


\section{Statistical Discourse on Domestic Violence against Women in Lithuania}

It has already been stated that legal regulations lack evident protection measures and victims of violence lack legal and social assistance. Yet, the significance of the adoption of the law on the protection against domestic violence in the Republic of Lithuania and the impact of the law in terms of promoting the publicity attitude towards the problem of domestic violence and reporting about domestic criminal offenses is immense. The statistical data which cover the period between 2007-2016 manifest the society attitude towards this serious and "eternal" problem (see tables 1 and 2).

Table 1. Number of women affected by domestic crime

\begin{tabular}{|c|c|c|c|c|c|c|c|c|c|c|}
\hline & \multicolumn{10}{|c|}{ Affected by a spouse, partner or cohabitant } \\
\hline & Year & Year & Year & Year & Year & Year & Year & Year & Year & Year \\
\hline & 2007 & 2008 & 2009 & 2010 & 2011 & 2012 & 2013 & 2014 & 2015 & $2016 \mathrm{~m}$. \\
\hline Total & 418 & 359 & 321 & 334 & 618 & 4582 & 5635 & 5325 & 5235 & 4319 \\
\hline In rural areas & 166 & 158 & 131 & 155 & 247 & 1886 & 2506 & 2258 & 2184 & 1772 \\
\hline $\begin{array}{l}\text { Murder } \\
\text { (CC, Art. 129-130) }\end{array}$ & 18 & 18 & 19 & 21 & 17 & 11 & 19 & 15 & 14 & 8 \\
\hline $\begin{array}{l}\text { Severe Health } \\
\text { Impairment } \\
(\mathrm{CC}, \text { Art. 135-136) } \\
\end{array}$ & 9 & 10 & 8 & 7 & 6 & 5 & 7 & 3 & 4 & 9 \\
\hline $\begin{array}{l}\text { Non-severe Health } \\
\text { Impairment } \\
(\mathrm{CC}, \text { Art. } 138)\end{array}$ & 149 & 137 & 102 & 93 & 128 & 264 & 145 & 75 & 61 & 86 \\
\hline $\begin{array}{l}\text { Causing Physical } \\
\text { Painor a Negligable } \\
\text { health Impairment } \\
\text { (CC, Art. 140) }\end{array}$ & 44 & 61 & 44 & 42 & 234 & 3683 & 4916 & 4742 & 4747 & 3730 \\
\hline $\begin{array}{l}\text { Threatening to Murder } \\
\text { or Cause a Severe } \\
\text { health Impairment } \\
\text { to a Person or } \\
\text { Terrorisation of a } \\
\text { Person (CC, Art. 145) }\end{array}$ & 100 & 55 & 81 & 91 & 143 & 610 & 571 & 508 & 433 & 457 \\
\hline $\begin{array}{l}\text { Rape, Sexual Assault, } \\
\text { Sexual Abuse } \\
(\mathrm{CC}, \text { Art. 149-151) }\end{array}$ & 5 & 4 & 8 & 11 & 12 & 6 & 8 & 8 & 5 & 9 \\
\hline
\end{tabular}

Būk stipri. Statistika, 2017 (Statistics, 2017. Data taken from the Departmental Register of Criminal Offences (Information Technology and Communications Department under the Ministry of Internal Affairs of the Republic of Lithuania) 
Table 2. Number of women affected by domestic crime

\begin{tabular}{|l|c|c|c|c|c|c|c|c|c|c|}
\hline \multicolumn{1}{|c||}{} & \multicolumn{7}{|c|}{ Affected by children and foster-children } \\
\cline { 2 - 13 } & $\begin{array}{r}\text { Year } \\
2007\end{array}$ & $\begin{array}{r}\text { Year } \\
2008\end{array}$ & $\begin{array}{r}\text { Year } \\
2009\end{array}$ & $\begin{array}{r}\text { Year } \\
2010\end{array}$ & $\begin{array}{r}\text { Year } \\
2011\end{array}$ & $\begin{array}{r}\text { Year } \\
2012\end{array}$ & $\begin{array}{r}\text { Year } \\
2013\end{array}$ & $\begin{array}{r}\text { Year } \\
2014\end{array}$ & $\begin{array}{r}\text { Year } \\
2015\end{array}$ & $\begin{array}{c}\text { Year } \\
2016\end{array}$ \\
\hline Total & $\mathbf{9 6}$ & $\mathbf{9 6}$ & $\mathbf{9 6}$ & $\mathbf{1 0 3}$ & $\mathbf{1 3 9}$ & $\mathbf{7 3 0}$ & $\mathbf{8 9 8}$ & $\mathbf{9 1 4}$ & $\mathbf{8 5 1}$ & $\mathbf{7 3 0}$ \\
\hline In rural areas & 38 & 41 & 48 & 48 & 59 & 324 & 419 & 385 & 392 & 325 \\
\hline $\begin{array}{l}\text { Murder } \\
\text { (CC, Art. 129-130 ) }\end{array}$ & 5 & 8 & 6 & 5 & 6 & 2 & 2 & 1 & 4 & 1 \\
\hline $\begin{array}{l}\text { Severe Health Impairment } \\
\text { (CC, Art. 135-136) }\end{array}$ & 3 & 4 & - & 1 & 1 & 3 & - & - & - & 1 \\
\hline $\begin{array}{l}\text { Non-severe Health } \\
\text { Impairment } \\
\text { (CC, Art. 138) }\end{array}$ & 25 & 23 & 20 & 28 & 23 & 32 & 16 & 14 & 11 & 19 \\
\hline $\begin{array}{l}\text { Causing Physical Painor } \\
\text { a Negligable health } \\
\text { Impairment (CC, Art. 140) }\end{array}$ & 9 & 10 & 8 & 6 & 32 & 506 & 712 & 724 & 708 & 544 \\
\hline $\begin{array}{l}\text { Threatening to Murder } \\
\text { or Cause a Severe health } \\
\text { Impairment to a Person or } \\
\text { Terrorisation of a Person } \\
\text { (CC, Art. 145) }\end{array}$ & 14 & 11 & 14 & 19 & 38 & 164 & 140 & 128 & 106 & 139 \\
\hline $\begin{array}{l}\text { Rape, Sexual Assault, } \\
\text { Sexual Abuse } \\
\text { (CC, Art. 149-151) }\end{array}$ & - & - & 1 & - & - & - & 1 & - & - & - \\
\hline
\end{tabular}

Būk stipri. Statistika, 2017 (Statistics, 2017. Data taken from the Departmental Register of Criminal Offences (Information Technology and Communications Department under the Ministry of Internal Affairs of the Republic of Lithuania)

Data provided in Table 1 and Table 2 illustrate the growth of record level of domestic violence against women from their spouses, partners or cohabitants. The number of recorded cases has grown by eight times, i.e. from hundreds to thousands of cases of domestic violence. The similar parallel is evident in Table 2 which provides the numbers of cases of domestic violence against women from their children and foster-children.

The number of records when police is called to homes of victims has also increased. The attention should be drawn to year 2013 which is considered to be a culminating point in the context of the provided statistical data.

In 2013 the Police Department under the Ministry of Interior of the Republic of Lithuania recorded 21600 police calls for domestic abuse. They resulted in more than 10000 prie-trial investigation cases. The affected people included $82 \%$ of women, $11 \%$ of men and $7 \%$ of children. In comparison with statistical data of 
the year 2012 when the law on protection against domestic violence gained the publicity, the number of police calls for domestic abuse increased by $20 \%$ and the number of prie-trial investigation cases of domestic violence increased by $30 \%$ (On 2014-2020 Programme on Prevention of Domestic Violence and Provision of Assistance to Victims).

In 2017 the number of persons who suffered from domestic violence was 4700 persons in a city (57.5\%) and 3500 persons in rural areas $(42.5 \%)$. The majority of affected people were women (5600 or $82 \%$ ) and $79.2 \%$ of them were abused by their intimate partner.

In 2017 the total number of people suspected (accused) of domestic violence reached 6131persons. Among them men constituted 91\%. More than half of suspected (or accused) persons were of age between 30 and 40 . There were also 40 under-age persons suspected (or accused) of committing domestic violence $(0.8 \%$ of the total number of suspected (or accused) of domestic violence). The education background of suspected (or accused) persons was the following: secondary or professional education $-56.3 \%$, basic education $-23.3 \%$, university or higher education $-10.4 \%$ and elementary education or no education $-10 \%$. Half of people $(50.8 \%)$ were unemployed or did not study when they committed a crime or abuse. At the time of the crime $60.2 \%$ of persons were intoxicated with alcohol or narcotic substances. The majority of them (5800 persons or $94.8 \%$ ) of suspected (or accused) of physical violence.

In 2017 Police Department registered total 47900 reports of domestic violence (Lietuvos statistikos departamentas [Lithuanian Department of Statistics], 2017).

Summing up the provided statistical construct, it can be stated that the Law on Protection against Domestic Violence has a positive impact on the perception of the problem of violence against women. It forces society not to tolerate the manifestations of violence, and also denies the stereotypes existing in real and virtual life, that only the so-called risk families experience violence in the immediate environment. N. Dirsienè (2005) states that existing myths confuse the society attitude towards women who are victims of violence, including the determination of such women to seek for help.

In Lithuania, as well as other countries, the most wide-spread form of violence is physical violence. The physical violence means beating by hand or with help of different items, the expression of blows, push or strangle that lead to bodily harm or even death of an abused person (see tables 1 and 2). The EU survey of 2014 revealed that around $31 \%$ of women experienced physical violence one or more times (Smurtas prieš moteris ES masto apklausa [Violence against women: an EUwide survey], 2014). 


\section{The support system for women in the context of domestic violence}

D. Puidokiene (2002) states that women affected by domestic violence have always been assisted with provision of medical, psychological or legal support and that diverse preventive measures have always been implemented. Emergency medical care is often needed when, in the case of physical or sexual violence, the victim is injured by being beaten up or otherwise using a physical force against a woman. Women frequently do not seek help immediately after an event. They often appeal for help after some time, and that makes the assistance more difficult to deal with. Police officers used to be the first to provide legal assistance and counselling to women who suffered from domestic violence while they were called to family conflict sites and encountered with victims. Women usually hesitated in making a written statement. Police officers and medical staff would encourage a victim to file a report, however it was a victim who ultimately would make a decision. The primary research indicates that only $10.6 \%$ of victims notified about experienced domestic violence and only $21 \%$ of these turned to police for assistance (Purvaneckienè, 1999, p. 90). This was also due to the lack of experience and non-interference to "internal family disagreements" approach on behalf of police officers who communicated with victims of domestic violence. In Lithuania the provision of psychological or psychotherapeutic assistance to women who suffered from domestic violence has been adequate from the outset. When the problem of domestic violence against women in Lithuania was identified various psychological support services started to be established (Youth, peer support centres, Hope line, anonymous psychological support services). The assistance provided by these services has been very significant because it is anonymous, the fact which is still of great relevance in our society, and because any person, even those living in the farthest spot of Lithuania, have been able to reach it. Group therapy has also been introduced. Self-help groups became critical. All this put the fundamentals for establishment of specialized and comprehensive assistance. Today, one can assert that the Law of the Republic of Lithuania on Protection against Domestic Violence provided the opportunity to form a new system of assistance in the fight against violence that occurs in the immediate environment of a person, i.e. at home. The system of specialized assistance has been developed using the existing experience of women's non-governmental organizations from Lithuania and foreign countries.

According to the Government of the Republic of Lithuania Resolution No. 1066 On the Implementation of the Law of the Republic of Lithuania on Protection against Domestic Violence (Dèl Lietuvos Respublikos apsaugos nuo smurto artimoje aplinkoje ịstatymo ịgyvendinimo, 2011) issued on September 14, 2011, Ministry of Social Security and Labor, Ministry of Health and Ministry of Inte- 
rior issued Order No. A1-534 / V-1072 / 1V-931 On Approval of Programmes at Specialised Assistance Centres (Dèl specializuotos pagalbos centru programu patvirtinimo, 2011). It was a timely and long-awaited document that opened the door to further development of infrastructure strategy for women's aid. The process resulted in Order (No. A1-227) On the Approval of the Description of Activities of Specialized Assistance Centres (Dèl specializuotos pagalbos centrų veiklos aprašo patvirtinimo, 2012) issued by Ministry of Social Security and Labor of the Republic of Lithuania on May 7, 2012. The first specialized assistance Centres began operating in September 2012. Together with partners in the framework of joint activity agreements, they started the provision of specialized assistance to victims of violence throughout Lithuania. During the first year of their functioning 5000 victims of violence, of whom $90 \%$ were women, were granted specialized assistance.

The Law of the Republic of Lithuania on Protection against Domestic Violence stipulates that Specialised Assistance Centre is an institution performing public functions and providing specialized comprehensive assistance to the victims of violence. All residents of Lithuania, no matter what municipality they live in, can address them. The functions of Specialised Assistance Centres (hereinafter: SAC) include providing information, counselling and mediation in psychological and legal assistance. The provision of information includes the provision of a comprehensive package of support services. A person who has experienced violence in the immediate environment together with a counsel or make an action and assistance plan for coordination of the further specialized assistance. In order to achieve the most effective result, the SAC work in cooperation with municipal institutions, local authorities, NGOs that provide assistance to victims of violence, institutions providing accommodation services, police, health care institutions and institutions that provide legal services. Currently, there are about 50 SAC throughout Lithuania. The development of SAC is both a product and an endless improvement process.

\section{In conclusion}

Domestic violence is a problem that is relevant both in Lithuania and abroad. For a long time, the system of protection of human rights in Lithuania has experienced a lack of laws that would directly protect women-victims of violence and legal norms that would regulate the ways of helping them. Therefore, in the Lithuanian society, domestic violence has long been understood as the family problem but not society problem. To eliminate various myths, violence occurs in families of different social status, it is not limited to specific age groups and it is independent 
of religion. The causes of violence are very diverse: from patriarchal family relationship, alcohol and drug addiction, poverty and social exclusion, misconduct, previously experienced abuse or exploitation, to moral degradation. The well-established social beliefs that tolerate discrimination against women also have a significant impact on the emergence of violence. It is believed that the dominant form of violence in our society is physical violence because it is "visible". Domestic violence is damages the quality of life of the victim, undermines self-esteem and has a negative impact on career planning. Children who live in families that experience violence are also negatively affected. They can take over the culture of domestic violence and use it when they grow up.

The article presents the legal discourse which reveals that the consistent implementation of the strategy of legal protection against violence in the immediate environment enables the creation of a specialized comprehensive assistance infrastructure throughout the country, provides access to appropriate medical, psychological, legal assistance and entitles the society to develop prevention programmes that help to establish intolerance towards violence. Social workers play acritical role in the assistance system infrastructure. Their functioning will be the research object in the future articles.

\section{References}

Apsaugos nuo smurto artimoje aplinkoje istatymo priemimo istorija. (2010-2011). Prieiga internete: <http://www. vmotnam.lt/apsaugos-nuo-smurto-artimoje-aplinkoje-istatymo-priemimo-istorija/ [žiūrèta 2017-12-07].

Būk stipri. Statistika. (2017). Informatikos ir ryšiu departamento prie Vidaus reikalu ministerijos duomenys apie ikiteisminio tyrimo ịstaigose užregistruotus asmenis, nukentėjusius nuo nusikalstamu veiku, susijusiu su smurtu artimoje aplinkoje. Prieiga internete: http://bukstipri.lt/lt/statistika.html

Deklaracija dèl smurto prieš moteris panaikinimo. (1993). Jungtinių Tautų generalinè asamblèja. Prieiga internete: http://eur-lex.europa.eu/legal-content/LT/TXT/?uri=CELEX:52008IR0267 [žiūrèta 2017-02-01].

Dèl Lietuvos Respublikos apsaugos nuo smurto artimoje aplinkoje įstatymo igyvendinimo. (2011). LR Vyriausybės nutarimas Nr. 1066. Valstybès žinios, Nr. 115-5400.

Dèl specializuotos pagalbos centru programu patvirtinimo. (2011). LR Socialinès apsaugos ir darbo, Sveikatos apsaugos ir Vidaus reikalų ministrų 2011 m. gruodžio 19 d. ịsakymas Nr. A1-534/V-1072/1V-93. Prieiga internete: https://e-tar.lt/portal/lt/legalAct/TAR.24DEC6E8C6F9 [žiūrèta 2018-02-05].

Dèl specializuotos pagalbos centru veiklos aprašo patvirtinimo. (2012). LR Socialinès apsaugos ir darbo ministro isakymas Nr. A1-227. Prieiga internete: https://www.e-tar.lt/portal/lt/legalAct/TAR.EE22DE5E3F98 [Žiūrèta 2018-02-15].

Dèl valstybinès smurto artimoje aplinkoje prevencijos ir pagalbos teikimo nukentëjusiems asmenims 2014-2020 metu programos patvirtinimo. (2014). LR Vyriausybės 2014 m. gegužès 28 d. nutarimas Nr. 485 Prieiga internete: https://www.e-tar.lt/portal/lt/legalAct/6f8ae420242611e78397ae072f58c508 [žiūrèta 2017-1105].

Dirgèlienè, I., Jundulaitė, O. (2011). Smurtą šeimoje patyrusių ir / ar patiriančių moterų resocializacija krizių centre. Sveikatos mokslai, Nr. 7(21), p. 66-69.

Dirsienė, N. (2005). Patarimai teikiantiems pagalba šeiminio smurto aukoms. Vilnius: Moterų informacijos centras.

Dirsienè, N., Reikertienė, V. (2008). Smurtinio elgesio keitimo metodika: praktinis vadovas socialiniams darbuotojams. Vilnius: Lygių galimybių plètros centras. 


\section{DOMESTIC VIOLANCE AGAINST WOMEN: DISCOURSE OF REALITY}

Gaigalienė, M. (2002). Šeimos funkcijų tyrimo pedagoginiai aspektai. Pedagogika, Nr. 60, p. 84-85. Vilnius: VPU.

Gustaitienè, M. (2005). Smurto prieš moteris priežastys ir prevencija. Sociologija. Mintis ir veiksmas, Nr. 1 (15), p. $110-21$.

Kanopienė, V., Pavilionienė, M. A. (1997). Smurtas prieš moteris ir vaikus Lietuvoje. Vilnius: Moterų informacijos centras.

Lietuvos Respublikos Konstitucija. (2002). Valstybès žinios, 1992, Nr. 33-1014, 2 straipsnis. Prieiga internete: http://konstitucija.lt/lt/konstitucija/21-straipsnis/ [žiūrèta 2017-12-08].

Liobikienè, N. (2006). Kriziu intervencija. Kaunas: VDU.

LR Apsaugos nuo smurto artimoje aplinkoje istatymas. (2011). 2011 m. gegužès 26 d., Nr. XI-1425. Valstybès žinios, Nr. 72-3475. Prieiga internete: https://www.e-tar.lt/portal/lt/legalAct/TAR.E14E65020CCC [žiūrèta 2017-12-05].

LR baudžiamasis kodeksas. (2000). Valstybès žinios, Nr. 89-2741.

LR baudžiamasis kodeksas. (2015). Prieiga internete: https://www.e-tar.lt/portal/lt/legalActEditions/ TAR.2B866DFF7D43?faces-redirect=true [žiūrèta 2018-02-10].

Meškauskaitè, L. (1999). Lengvas kūno sužalojimas ar smūgių sudavimas. Praktiniai patarimai smurta patyrusioms moterims. Vilnius: Moterų informacijos centras.

Miškinis, K. (2003). Šeima žmogaus gyvenime. Kaunas: Aušra.

Moteru informacijos centro tyrimo ataskaita. (2004). Prieiga internete: www.moteruinformacijoscentras.lt/wpcontent/uploads/2016/03/MIC-2004.pdf

Navaitis, G. (1999). Lietuvos šeima: psichoterapinis aspektas. Vilnius: Tylo alba.

Nusikaltimy auku teisiu direktyva: naujas požiūris ị artimuju smurto aukas. (2014). Vilnius: Žmogaus teisiu stebejjimo institutas. Prieiga internete: <http://www. hrmi.lt/uploaded/Apzvalgos/Tyrimas_auku-teisiudirekt_1.pdf [žiūrèta 2018-01-25].

Palavinskienè, B. (2001). Smurto šeimoje prevencija: užsienio šalių patirtis. Jurisprudencija, T. 20 (12), p. 59-67. Vilnius:

Pavilionienè, M. A. (1998). Lyčiu drama. Vilnius: VU.

Policijos departamento pranešimas apie smurta artimoje aplinkoje. (2017). Lietuvos statistikos departamentas. Prieiga internete: https://osp.stat.gov.lt/naujienos?articleId=5558717 [žiūrèta 2018-02-05].

Policijos departamento prie Vidaus reikaly ministerijos duomenys, susiję su smurtu artimoje aplinkoje. (20072016). Prieiga internete: http://www.bukstipri.lt/lt/statistika [žiūrèta 2018-02-06].

Puidokienè, D. (2002). Moteru, patyrusių smurta šeimoje, resocializacija. Magistro tezès. Klaipèdos universitetas, Socialinio darbo katedra.

Purvaneckienè, G. (2000). Smurtas prieš moteris. Moterys Lietuvoje. Moteru informacijos centras, p. 94-101. Vilnius:

Purvaneckienė, G. (1999). Smurtas prieš moteris Lietuvoje. Motery informacijos centras. Vilnius: Danielius.

Purvaneckienè, G., Purvaneckas, A. (2001). Moteris Lietuvos visuomeneje: palyginamoji tyrimu analizė. Vilnius: Danielius.

Reingarde, J., Tamutiene, I. et al. (2010). Prevalence Study of Violence and Abuse against Older Women. Results of the Lithuanian Survey (AVOW Project). Lithuania: Vytautas Magnus University.

Reingardienè, J. (2004). Prievartos prieš moterị teorinis diskursas Vakarų šalyse: integruoto konceptualaus modelio paieškos. Socialiniai mokslai, Nr. 3 (45), p. 7-17.

Rezoliucija dèl smurto prieš moteris panaikinimo. (2009). Nr. 2010/C 285 E/07. Europos Parlamentas. Prieiga internete: http://eur-lex.europa.eu/legal-content/LT/TXT/?uri=CELEX:52009IP0098(01) [žiūrèta 201712-05].

Rutkauskienė, S., Gudliauskaitė-Godvadè, J. (2011). Lyčių stereotipai socialiniame darbe su socialinès rizikos šeimomis. Socialinis darbas. Patirtis ir metodai, Nr. 7 (1), p. 71-87.

Smurtą šeimoje patyrusių ir / ar patiriančiu moterų resocializacija krizių centre. (2011). Sveikatos mokslai, Nr. 7(21), p. 66-69.

Smurtas artimoje aplinkoje. (2018). Informatikos ir ryšiu departamentas prie LR Vidaus reikalų ministerijos. Prieiga internete: https://osp.stat.gov.lt/naujienos?articleId=5558717

Smurtas prieš moteris ES masto apklausa. (2014). Prieiga internete: fra.europa.eu/sites/default/files/fra-2014vaw-survey-factsheet_lt.pdf [žiūrèta 2018-02-05].

Šeimos kriziu prevencija, socialinès ir psichologinès pagalbos šeimai būdai. (2008). Vilnius: Lodvila. 
ArūnasAcus, ElvyraAcienė, Dalia Puidokienè

Vaigè, L. (2013). The Concept of Domestic Violence in Lithuania and the Aspect of Gender from the Perspective of International Law. Socialiniu mokslų studijos, Nr. 5 (1), p. 255-274.

Vaigè, L. (2016). Fundamentali moters teisè būti laisvai nuo smurto: išliekančios spragos. Prieiga internete: http://manoteises.lt/straipsnis/fundamentali-moters-teise-buti-laisvai-nuo-smurto-isliekancios-spragos/ [žiūrèta 2017-12-10].

Zaksaitè, S. (2014). Apsauga nuo smurto artimoje aplinkoje. In L. Beliūnienè, K. Ambrazevičiūtè, M. Lankauskas ir kt. Aktualiausios žmogaus teisių užtikrinimo Lietuvoje 2008-2013 m. problemos: teisinis tyrimas. Monografija. Internetinis leidinys. Vilnius: Lietuvos teisès institutas. 